\title{
SubSTANTIVE EquALITY REVISITED ${ }^{1}$
}

\section{Introduction}

The right to equality is a central commitment in human rights law. The aspiration towards equality resonates powerfully in the preambles of a multiplicity of human rights instruments and domestic constitutions, and the right to equality and non-discrimination are invariably among the core rights enumerated in these instruments. Yet the meaning of the right to equality is deeply contested. Westen for one argues that 'equality is an idea that should be banished from moral and legal discourse as an explanatory norm. ${ }^{2}$ For others, the right to equality does not go far enough. Even if equality before the law has been established, disadvantage persists, and this disadvantage tends to be concentrated in groups with a particular status, such as women, people with disabilities, ethnic minorities and others. ${ }^{3}$

These concerns have led to the quest for more sophisticated conceptions, moving from a formal understanding focussed on like treatment, to more substantive conceptions. Both the Supreme Court of Canada ${ }^{4}$ and the South African Constitutional Court ${ }^{5}$ have embraced the principle of substantive equality in interpreting the right to equality, a trend reflected at international level. ${ }^{6}$ Nevertheless, the meaning of the right to substantive equality remains elusive. Scholars, legislators and judges have elucidated various core meanings, chief amongst them, equality of results, equality of opportunity, and dignity. These in turn are reflected to some degree in legal formulae, such as unfair discrimination, disparate impact or

\footnotetext{
${ }^{1}$ The author would like to thank [my colleagues: to be added subsequently].

${ }^{2}$ Peter Westen, The Empty Idea of Equality, 95 HARVARD L. REV. 537, 542 (1982).

${ }^{3}$ Gwen Brodsky \& Shelaigh Day, Beyond the Social and Economic Rights Debate: Substantive Equality Speaks to Poverty, 14 CAN J. WOMEN \& L. 185 (2002).

${ }^{4}$ Law v Canada [1999] 1 SCR 497 (Canadian Supreme Court)

${ }^{5}$ Prinsloo v Van der Linde (CCT4/96), [1997] ZACC 5 (South African Constitutional Court)

6 The CEDAW Committee, 'General Recommendation No.25: on temporary special measures' (2004) $\mathrm{CEDAW} / \mathrm{C} / \mathrm{GC} / 25$.
} 
indirect discrimination, reasonable accommodation and harassment. Meanwhile, in the US Supreme Court, conservative justices regard substantive equality as highly problematic. ${ }^{7}$

It is argued in this paper that, whereas it is clear that the right to equality should move beyond a formal conception that likes should be treated alike, a substantive conception resists capture by a single principle. Instead, drawing on the strengths of the familiar principles in the substantive equality discourse, a four dimensional principle is proposed: to redress disadvantage; to address stigma, stereotyping, prejudice and violence; to enhance voice and participation; and to accommodate difference and achieve structural change. ${ }^{8}$ Behind this is the basic principle that the right to equality should be located in the social context, responsive to those who are disadvantaged, demeaned, excluded, or ignored.

The four dimensional approach aims at providing an analytic framework to illuminate better the multi-facetted nature of inequality and to assist in determining whether actions, practices or institutions impede or further the right to equality. It is deliberately framed in terms of dimensions, to permit us to focus on their interaction and synergies, rather than asserting a pre-established lexical priority. In this way, we are able to understand the manner in which different dimensions might be used to buttress one another. Where there are conflicts, or one cuts across another, the tension might be resolved by referring to the framework as a whole, the aim being, not so much to insist that one has priority, but to create a synthesis which takes account of all the dimensions. For example, while dignity should be furthered, this should not be at the expense of redressing disadvantage. Similarly, affirming difference and identity should be circumscribed by the need to prevent stigma, stereotyping and prejudice. It is acknowledged that the boundaries between the dimensions can be fluid; but it is argued that it is analytically useful to keep them separate.

The framework does not of course attempt to resolve all of the issues relating to the right to substantive equality. The aim of the multi-dimensional approach is ultimately an evaluative one, to provide a set of criteria to determine whether a law, policy, practice or institution is likely to fulfil the right to equality and to point to ways in which they should be reformed

\footnotetext{
${ }^{7}$ Martha Minow, IN Brown's WaKe 30 (2010) Ricci v. DeStefano 557 U.S. 557 (2009) (US Supreme Court); Parents Involved in Community Schools v Seattle School District 551 U.S. 701 (2007) (US Supreme Court).

${ }^{8}$ SANDRA FREDMAN, DISCRIMINATION LAW (2011); Sandra Fredman, The Future of Equality in Great Britain, Working Paper Series No.5 ed., EOC. 2002.
} 
better to do so. For example, social welfare systems based on conditional cash transfers might appear to advance the material disadvantage of people in poverty. But do they fulfil the right to substantive equality for women and if not, how can they be reshaped $?^{9}$

\section{Part I Background and methodology}

My concern as a human rights lawyer is with the evolving meaning of the right to equality in international and domestic human rights law. I do not aim to explicate a conception of equality in the abstract which would meet the objections of those philosophers who have attempted to do so. I have always recognised that the choice between different conceptions of equality is not one of logic but of values or policy. ${ }^{10}$ My approach is rooted in existing understandings. Although the right to equality is an open-textured principle, it is not an empty vessel which can contain any meanings one cares to attribute to it. The concept of substantive equality must build on and develop existing understandings of the right to equality in the law and literature. But neither is my aim to find a conception which, in a Dworkinian sense, is the 'best fit', making sense of the existing principles. ${ }^{11}$ There are too many conflicting understandings of the right to equality to find one underlying principle which makes sense of existing interpretations. The project is therefore rooted in existing understandings, but also self-consciously participates in the ongoing evolution of a right to substantive equality. In particular, I argue that the right to equality should be capable of responding to real wrongs. My aim then is to find and extrapolate from those understandings of substantive equality which are sensitive to the wrongs experienced by women and other out-groups on account of their status. Although there is no single consensus, there is sufficient consensus in relation to some principles to give credibility to the project of extrapolating from those principles. It is also possible, through ongoing engagement and discussion, to create new consensuses. ${ }^{12}$

\footnotetext{
${ }^{9}$ SANDRA FREDMAN, Engendering Social Welfare Rights, in WOMEN'S RIGHT TO SOCIAL SECURITY AND SOCIAL PROTECTION (Beth Goldblatt \& Lucie Lamarche eds., 2015).

${ }^{10}$ FREDMAN, DISCRIMINATION LAW, supra note 8 , at 2.

${ }^{11}$ Hugh Collins, Discrimination, Equality and Social Inclusion, 66 M.L.R. 16 (2003).

${ }^{12}$ For their seminal contributions see Cathi Albertyn, Substantive Equality and Transformation in South, 23 SAJHR 253 (2007); Cathi Albertyn and Beth Goldblatt, Facing the Challenge of Transformation: Difficulties in the Development of an Indigeous Jurisprudence on Equality, 14(2) S.A.J.H.R. 248 (1998) ; Judy Fudge, Substantive Equality, the Supreme Court of Canada, and the Limits to Redistribution 23 SAJHR 235 (2007); C. MacKinnon, Feminism Unmodified: Discourses on Life and Law. Cambridge, Mass.: Harvard Univ. Press, 1987; C. MacKinnon, Reflections on Sex Equality under Law." 100 Yale L. J. 1281 (1991); C. MacKinnon,
} 
This paper draws on comparative legal materials primarily from the US, UK, Canada and South Africa, in order to ground the conception of substantive equality in the experience of four English-speaking countries which have been at the forefront of the development of the right to equality at domestic level. The US, Canada and South Africa all have an entrenched constitutional right to equality. The UK has a sophisticated statutory framework, which is complemented by the EU and the ECHR, now incorporated in the Human Rights Act. In all these jurisdictions, several substantive conceptions of equality have jostled with the equal treatment principle for prominence. These include indirect discrimination or disparate impact, reasonable accommodation, affirmative action, systemic discrimination, and unfair discrimination.

Although formulated differently, these rights are built around a central core. The most open ended is the US Fourteenth Amendment, which states simply that 'No state shall ...deny to any person the equal protection of the laws.' Both Canada and South Africa have a general equality guarantee together with a more specific prohibition of discrimination on the basis of a partially enumerated list of grounds. ${ }^{13}$ Both have express provision for affirmative action. The UK statutory framework has recently been consolidated in the Equality Act 2010, which has provision for direct discrimination, indirect discrimination, reasonable adjustment, and victimisation, but only very limited provision for affirmative action. ${ }^{14}$ It does, however, include provision for proactive action on the part of public authorities to have 'due regard' to the need to promote equality of opportunity and good relations. ${ }^{15}$ Article 14 of the ECHR, incorporated into the Human Rights Act 1998, requires the rights and freedoms in the Convention to be secured without discrimination on a non-exhaustive list of prohibited grounds. ${ }^{16}$ The right to equality in international human rights law is generally defined in

'Gender in Constitutions' in THE OXFORD HANDBOOK OF COMPARATIVE CONSTITUTIONAL LAW (Michel Rosenfeld and András Sajó ed., OUP, 2012). . For the UK debate, see Sandra Fredman and Sarah Spencer, Beyond Discrimination: It's Time for Enforceable Duties on Public Bodies to Promote Equality Outcomes, 6 E.H.R.L.R. 598 (2006).

${ }^{13}$ Canadian Charter of Rights and Freedoms, Part I of the Constitution Act, 1982 enacted as Schedule B to the Canada Act 1982 (U.K.) 1982, c. 11 s 15; Constitution of the Republic of South Africa, 1996, s 9.

${ }^{14}$ Equality Act 2010 (UK), ss 13, 19. See further BOB HEPPLE, EQUALITY: THE NEW LEGAL FRAMEWORK (2011).

${ }^{15}$ Equality Act 2010 (UK) s 149. See Sandra Fredman, The Public Sector Equality Duty, 40(4) I.L.J. 405 (2011).

${ }^{16}$ Protocol 12 to the ECHR (ETS No. 177), which has not been ratified by the UK applies also to 'any right set forth by law' and proscribes discrimination by public bodies on any of the grounds in the same non-exhaustive list. 
open-textured terms. The central covenants simply refer to an obligation on States to ensure human rights without 'distinction', 'discrimination', 'exclusion', or 'restriction' or 'on the basis of equality' in relation to a non-exhaustive list of grounds.

This paper addresses the right to equality in relation to particular groups or identities. It does not enter into the debate about the distinction between the right to equality and nondiscrimination, except to suggest that the differences between them are pragmatic rather than logical. Most constitutional and international equality guarantees are expressed in terms of one or the other or both, and different jurisdictions delineate the distinctions between them in different ways. Nor does the paper examine the ways in which grounds for discrimination are or should be determined. Nevertheless, the substantive understanding of the right to equality is developed here in a discrimination context; in other words, to address wrongs experienced particularly on grounds of gender, race, disability, sexual orientation etc. as well as the intersection between these grounds. Part II briefly considers and critiques the central concept of equal treatment. Part III sets out some of the familiar candidates for substantive notions: equality of results, equality of opportunity and dignity. The advantages and limitations of each of these conceptions point the way to a multi-dimensional understanding, which I set out in Part IV.

\section{Part II The equal treatment principle: Treating likes alike}

The simplest and most ubiquitous statement of the principle of equality is the Aristotelean formula that likes should be treated alike. The principle that likes should be treated alike is possibly the most pervasive interpretation of the right to equality, largely in the form of prohibitions on direct discrimination ${ }^{17}$ or disparate treatment. A further manifestation is in the form of the right to equal pay for work of equal value, which allows a woman to claim equal pay if she is doing work of equal value with a male comparator in the same establishment.

It is this formulation which is the main target of Westen's critique. ${ }^{18}$ Not only do statements of equality 'logically entail (and necessarily collapse into) simpler statements of rights', but 'the additional step of transforming simple statements of rights into statements of equality

\footnotetext{
${ }^{17}$ Equality Act 2010 (UK), s. 13

${ }^{18}$ Westen, supra note 1 , at 540.
} 
not only involves unnecessary work but also engenders profound conceptual confusion. ${ }^{19}$ There is nothing in the formula itself, he argues, which indicates when two people are relevantly alike, and if they are alike, which treatment is at issue. ${ }^{20}$ Once it has been determined that two people are relevantly alike, the concept of equality becomes superfluous, since this determination simply states the eligibility requirement for a right. For example, the statement that all citizens have an equal right to vote is identical to the statement that all citizens have a right to vote. Westen does not, however, entirely dismiss the right to equality. For him, the equal protection clause in the Fourteenth Amendment has 'legal and moral substance' as an independent right. ${ }^{21}$ Although he broadly identifies this as the right to be free from racial injury, he notes that: 'Significantly, the courts thus far have failed to identify the precise sort of injury that the substance of the equal protection clause is designed to prohibit. ${ }^{22}$

This raises the question of what value the principle that likes should be treated alike might be pursuing. One straightforward possible value is the simple principle of consistency. Once it has been determined that two individuals or situations are relevantly alike, they should be treated the same for consistency sake. However, consistency alone is a minimal value, hardly worthy of the lofty claims of the right to equality. There are several reasons for this. Firstly, it does not solve the problem of when two individuals are relevantly alike, so as to attract consistent treatment. Not every distinction is discriminatory. Governments and individuals classify people into groups for a wide variety of reasons and many of them are legitimate. It is quite legitimate to distinguish between high-income and low-income groups for taxation reasons. On the other hand, for many years it was thought to be legitimate to distinguish women from men, blacks from whites. ${ }^{23}$ One of the biggest leaps in twentieth-century struggles for equality was the recognition that characteristics based on race, sex, colour, or ethnic origin should not in themselves constitute relevant differences justifying inferior

\footnotetext{
${ }^{19} \mathrm{Id}$. at 542.

${ }^{20} I d$. at $543-548$.

${ }^{21} I d$. at $565-6$.

${ }^{22} I d$. at 565 .

${ }^{23}$ FREDMAN, DISCRIMINATION LAW supra note 8, at 67-82.
} 
treatment. In other areas, such as sexual orientation, this recognition has still not been fully achieved.

The decision as to when likes should be treated alike is therefore one which requires recourse to principles outside of the formal equality formula. This has generally been a result of hard won gains through active engagements with the political process. The result of such struggles is reflected in fact that most constitutional or statutory guarantees include a list of grounds, going some way to addressing the question of when two individuals are relevantly alike by declaring which characteristics are irrelevant to that determination. Thus although the Fourteenth Amendment of the US Constitution simply declares that 'No State shall ... deny any person the equal protection of the laws', other Constitutions, such as the Canadian, South African and Indian, include a non-discrimination clause which specifies a list of grounds. ${ }^{24}$ This is true too for the ECHR, EU and UK. ${ }^{25}$ Even in relation to the Fourteenth Amendment, the US Supreme Court has partly filled this gap by its concept of 'suspect classes', primarily referring to race or alien status. ${ }^{26}$

This, however, is only part of the solution. Even where it is prescribed that two individuals are relevantly alike despite their race, sex etc., the equal treatment principle prescribes only that they should be treated the same. This is even narrower when the equal treatment principle is expressed as a prohibition on direct discrimination or disparate treatment, which proscribe treatment which is 'less favourable' on grounds of race, sex etc. ${ }^{27}$ However, to be treated the same might be of little value. This is because the principle that likes should be treated alike is fulfilled whether the two individuals are treated equally well or equally badly. Even more problematically, a claim of equal treatment can be met by removing a benefit from the relatively privileged group (levelling down). In a famous US case, the city of Jackson in Mississippi was ordered to desegregate its four 'whites only' swimming pools, together with the single 'blacks only' pool. Instead, it decided to close down all its public swimming pools. ${ }^{28}$ It was held that identical treatment had been applied to both whites and

\footnotetext{
${ }^{24}$ Canadian Charter, s 15; South African Constitution, s 9; Constitution of India, 1950 arts 14-16; European Convention on Human Rights, ETS 5, art14.

${ }^{25}$ Equality Act 2010 (UK), s 13.

${ }^{26}$ United States v Carolene Products Co., 304 U.S. 144 (1938), (US Supreme Court).

${ }^{27}$ See Equality Act 2010 (UK), s 13.
} 
blacks and that therefore there was no breach of the equality guarantee. Nor could it be said that one group was treated less favourably than the other on grounds of race. A similar response was seen in the UK in relation to legislation giving the authorities the power to detain non-UK nationals indefinitely without trial if they were suspected of international terrorism. ${ }^{29}$ The House of Lords struck down the legislation on the grounds, inter alia, that it applied only to non-UK nationals and not to UK nationals who might also be suspected of international terrorism. ${ }^{30}$ Since non-UK nationals and UK nationals were 'alike' in a relevant sense, they should be treated alike. The government responded by giving itself power to issue orders curtailing the liberty (again without trial) of both UK and foreign terrorism suspects. The principle of like treatment was satisfied by intruding equally on the liberty of both groups. ${ }^{31}$

It was this risk that led the majority of the US Supreme Court to avoid the right to equality when it finally decided to strike down legislation criminalizing homosexuality. Lawrence $v$ Texas concerned a Texas statute forbidding two persons of the same sex to engage in specified sexual intimacies. ${ }^{32}$ As Kennedy J put it: 'Were we to hold the statute invalid under the Equal Protection Clause some might question whether a prohibition would be valid if drawn differently, say, to prohibit the conduct both between same-sex and different-sex participants. ${ }^{33}$ To avoid such a levelling down option, the majority of the Court held instead that the statute constituted a breach of the substantive right of due process. Raz goes further and concludes that, in the field of distributive equality, the possibility of a levelling down option demonstrates that equality cannot have intrinsic value. He argues that belief in the intrinsic value of equality entails regarding 'equality [as] worthwhile even if it means

\footnotetext{
${ }^{28}$ Palmer v Thompson, 403 U.S. 217 (1971), (US Supreme Court).

${ }^{29}$ Anti-Terrorism,Crime and Security Act 2001 (UK), s 23.

${ }^{30}$ A v Secretary of State for the Home Department, [2004] UKHL 56 (HL).

${ }^{31}$ Sandra Fredman, From Deference to Democracy: the Role of Equality under the Human Rights Act 1998, 122 L.Q.R. 53 (2006).

${ }^{32}$ Lawrence v Texas, 539 U.S. 558 (2003), (US Supreme Court).

${ }^{33} I d$. at 575 .
} 
significantly lower level of realisation or instantiation of other values' ${ }^{34}$ This only makes sense if the simple experience of being equal is valuable, a proposition Raz rejects.

The second problem with equality as consistency is that it assumes that the same treatment is always appropriate. Yet, where there is antecedent disadvantage, 'like' treatment may in practice entrench difference. Thus unequal treatment may be necessary to achieve genuine equality. As Sen has argued: 'Equal consideration for all may demand very unequal treatment in favour of the disadvantaged.' 35

It could be argued that the background value is not simply consistency, but merit. The underlying assumption is that, once characteristics such as race, sex etc. are disregarded, individuals can be treated entirely on their merit. In the US, this takes the form of the 'anticlassification' principle, namely, that individuals should be treated on their own merit, regardless of their colour or race. ${ }^{36}$ However, this assumes that individual 'merit' can be considered in the abstract, apart from colour, religion, ethnic origins, gender, or other such characteristic. Yet an individual's social, economic, and political situation is still heavily determined by these very characteristics. The terms on which merit is judged are often a product of the dominant group: for example, women's time spent on child-care is usually ignored in assessing their qualifications for a job. Thus the basic premise, namely that there exists a 'universal individual', is deeply deceptive. Ultimately, like treatment can only be judged against the treatment accorded to a similarly situated comparator, who, far from being universal, is clothed with the attributes of the dominant gender, culture, religion, ethnicity, or sexuality. It is not a coincidence that, when we talk of ethnicity, we generally refer to ethnic minorities, rather than ethnic majorities, attributing 'normality' to the dominant culture rather than its own ethnic specificity.

The result is to create powerful conformist pressures. In feminist literature this has been dubbed the 'male norm'. Equality as consistency requires an answer to the question: 'Equal

\footnotetext{
34 Joseph Raz, On the value of distributional equality OXFORD UNIVERSITY LEGAL RESEARCH PAPER SERIES Paper No 41/2008 at 6; also found in JOSEPH RAZ, 'On the value of distributional equality' in

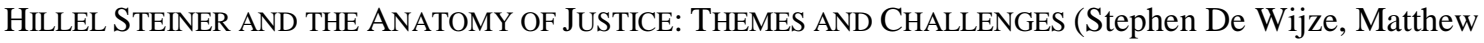
Kramer, and Ian Carter ed., Routledge, 2009).

35 AMARTYA SEN, INEQUALITY RE-EXAMINED (1992).

${ }^{36}$ See Reva Siegal, From Colorblindness to Antibalkanization: An Emerging Ground of Decision in Race Equality Cases, 120 YALE L. J. 1278 (2011).
} 
to whom?' The answer is, inevitably, 'equal to a man'. In the powerful words of Catharine MacKinnon: 'Concealed is the substantive way in which man has become the measure of all things. Under the sameness standard, women are measured according to our correspondence with man. . . Gender neutrality is thus simply the male standard. ${ }^{37}$, The assimilationist tendency has also been problematic in the context of religion and ethnicity. Parekh puts it starkly: 'The choice before the minorities is simple. If they wish to become part of and be treated like the rest of the community, they should think and live like the latter; if instead they insist on retaining their separate cultures, they should not complain if they are treated differently. ${ }^{38}$ The problem has been particularly acute in respect of pregnancy rights. On a strict view of equality as consistency, there is simply no appropriate male comparator and therefore no equality right arises. This difficulty was initially addressed by the unsatisfactory mechanism of comparing the treatment received by a pregnant woman with that of an ill man, an approach still current in the US. It was only when the court could move beyond the idea of equality as consistency and therefore beyond the need for a male comparator that real progress could be made. ${ }^{39}$

Even more fundamentally, this assumes that individual identities should be discarded. Yet each individual is constituted partly by group affinities,${ }^{40}$ whether it be her sense of identity, history, affinity with others, mode of reasoning, or expression of feelings. Of course, the major contribution of the right to equality has been its insistence that an individual should not be subjected to detrimental treatment on the basis of negative stereotypes attributed to her because of her race or sex. However, in rejecting the negative effects of taking group-based characteristics into account, the principle of equality has assumed that all aspects of group membership should be disregarded. Yet, diverse individual identities may be enriching and desired. This demonstrates that the problem is not the diversity of characteristics, but the detrimental treatment attached to them. Thus the aim should not be to eliminate difference,

\footnotetext{
${ }^{37}$ CATHERINE MACKINNON, FEMINISM UNMODIFIED 34 (1987).

${ }^{38}$ BHIKHU PAREKH, 'Integrating Minorities' in RACE RELATIONS IN BRITAIN 2 (Tessa Blackstone, Bhikhu Parekh, and Peter Sanders ed., 1998) .

${ }^{39}$ See further Sandra Fredman, A Difference with Distinction: Pregnancy and Parenthood Reassessed, 110

L.Q.R.106 (1994); SANDRA FREDMAN, WOMEN AND THE LAW 234 ff. (1997).

${ }^{40}$ IRIS MARION YOUNG, JUSTICE AND THE POLITICS OF DIFFERENCE 45 (1990).
} 
but to prohibit the detriment attached to such difference, preferably by adjusting existing norms to accommodate difference.

The principle that likes should be treated alike has a further difficulty. A breach of the right requires a showing that $\mathrm{Y}$ treated $\mathrm{X}$ less favourably than a similarly situated comparator on grounds of race, sex etc. This in turn means that a breach of the right to equality can only be made out if a perpetrator, Y, can be found. In the US, this has been reflected in the further insistence on discriminatory intent for proof of breach of the equal protection clause of the Fourteenth Amendment. ${ }^{41}$ In the UK context, although the courts have adamantly set their face against the need to prove purpose in a direct discrimination case, ${ }^{42}$ there is still the need to prove causation: 'but for' the applicant's protected characteristic, she would not have been treated less favourably. Yet sexism, racism, and other forms of discrimination extend far beyond individual acts of prejudice. Such prejudices are frequently embedded in the structure of society, and cannot be attributed clearly to any one person.

\section{Part III: Alternative Conceptions}

One way forward, as Westen suggests, is to abandon equality and opt for substantive rights. Recognising its limitations, however, does not necessarily entail abandoning the concept. Instead, courts and legislatures have moved towards more substantive interpretations of the right to equality. Different conceptions have been developed. While all fall under the broad umbrella of 'substantive equality,' the precise meaning of substantive equality remains contested. The next section considers several candidates. One broad approach is to answer the question 'equality of what' in a different way. Instead of equality of treatment, we aim for equality of results or equality of opportunity. A different broad approach is to look for substantive values, such as dignity. Part III considers equality of results, equality of opportunity and dignity as candidates for the meaning of substantive equality. Building on the insights gained from this discussion, Part IV sets out a multi-dimensional approach to understanding and applying substantive equality.

\footnotetext{
${ }^{41}$ Washington v Davis 426 US 229, 96 S Ct 2040 (1976) (US Supreme Court) and see C. MacKinnon, Toward a Renewed Equal Rights Amendment: Now More Than Ever 37(2) Harv. J. L. \& Gender (2014) 569.

42 James v Eastleigh Borough Council [1990] 2 AC 751 (UKHL); $R$ (on the application of E) v JFS Governing Body [2009] UKSC 15 (UK Supreme Court).
} 


\section{Equality of Results}

As we have seen, a key limitation of the equal treatment conception is its inability to address situations in which equal treatment entrenches antecedent inequalities. By focusing on results rather than treatment, it is possible to avoid this problem. Unequal treatment may be permitted or required in order to achieve equal results. While the equal treatment principle is based on a notion of procedural fairness stemming from consistent treatment, equality of results is concerned with a fairer distribution of benefits. ${ }^{43}$ Thus affirmative action, or preferential treatment of a disadvantaged group, while apparently breaching the equal treatment principle, is better understood as furthering equality of results. Similarly, the concept of disparate impact in US law proscribes neutral practices which nevertheless unjustifiably have unequal impact: "practices that are fair in form, but discriminatory in operation. ${ }^{44}$ By moving from treatment to results, proof of intent becomes unnecessary. In the seminal case of Griggs $v$ Duke Power, the US Supreme Court made it clear that 'good intent or absence of discriminatory intent does not redeem employment procedures or testing mechanisms that operate as "built-in headwinds" for minority groups and are unrelated to measuring job capability. ${ }^{, 45}$ Similarly, in the UK and EU, indirect discrimination refers to practices, policies or criteria which apply equally to all but put an individual at a disadvantage because of a protected characteristic, and which cannot be justified. ${ }^{46}$

The principle of equality of results, however, is challenging. What 'results' matter and what does 'equality' mean in that context? Theorists such as Parfit tend to focus on equality of well- being ${ }^{47}$, but the meaning of well-being is itself a subject of more than a little debate, and indeed, the radical consequences of insisting on equality of well-being tend to be used as

\footnotetext{
${ }^{43}$ J Gardner, 'Liberals and Unlawful Discrimination' (1989) 9 Oxford Journal of Legal Studies 1

${ }^{44}$ Griggs v. Duke Power Co. 401 U.S. 424 (1971) (US Supreme Court).

${ }^{45}$ Ibid. at 432. Intent had not been proved in the lower courts. Nevertheless, as well as addressing structural discrimination, disparate impact can be used to '(1) to smoke out covert discriminatory purpose; and (2) to challenge subconscious employer bias: R Siegal, 'From Colorblindness to Antibalkanization: An Emerging Ground of Decision in Race Equality Cases' [2011] 120 Yale Law Journal 1278 at1317.

${ }^{46}$ See Equality Act 2010 (UK), s.19; see also Ontario Human Rights Commission v. Simpsons-Sears Ltd, [1985] 2 S.C.R. 536, (Canadian Supreme Court); City Council of Pretoria v Walker (CCT8/97) [1998] ZACC 1; 1998 (2) SA 363; (South African Constitutional Court).

${ }^{47}$ Derek Parfait, Equality and Priority, 10 RATIO 202 (1997).
} 
a reason to reject egalitarianism. In discrimination law, the principle of equality of results is generally applied to workforce participation, places at schools or universities, or voting. But here the application of 'equality' becomes problematic. Should the results reflect the spread of all the identity groups in the population as a whole? This may be relatively easy to envisage in relation to gender or race. We might plausibly aim to achieve a balanced workforce or student body, with parity between women and men in all grades. But are we aiming to achieve a workforce, educational institution, or representative body which exactly reflects the population in relation to age, disability, religion or belief, and sexual orientation? And how do we factor in intersectional discrimination? As several jurisdictions have discovered, a simple focus on equality of results does not assist us in determining how we count representation of white women as against black men, and where we position groups with intersectional identities, such as older women, women with disabilities, gay women etc.

Nor is it obvious that equality of results resolves the levelling down problem. It is perfectly plausible to achieve equality of results by equalising everyone at a lower level: indeed, the critique of egalitarianism is primarily aimed at distributive solutions such as this. One way forward is to follow Parfit's 'prioritarian' approach. On this view, the focus is on the worse off. On any scenario, the gains to the worse off are given greater value than the gains to anyone else. As Parfit frames it, this is not an egalitarian claim. 'We do not think it in itself bad, or unjust, that some people are worse off than others... Egalitarians are concerned with relativities: with how each person's level compares with the level of other people. On the Priority View, we are concerned only with people's absolute levels. ${ }^{48}$ He concludes that this approach makes equality redundant: what matters are people's absolute entitlements, rather than their entitlements relative to others. However, absolute entitlements tend to settle at the minimum and do nothing to redress disparities above the minimum. It is here that equality continues to play a role. A clear example is the difference between the right to minimum pay, which is an absolute entitlement, and the right to equal pay for equal work for men and women, which is centrally and rightly concerned with disparities. Thus while substantive equality need not be about achieving purely egalitarian outcomes; it should at least in part aim to reduce the gap between the more disadvantaged and the less disadvantaged.

\footnotetext{
${ }^{48} I d$. at 214.
} 
There is a deeper problem with equality of results. This is that altering outcomes need not necessitate any fundamental re-examination of the structures that perpetuate discrimination. A change in the colour or gender composition of a grade or sector, while to some extent positive, might reflect only an increasingly successful assimilationist policy. Thus women who achieve these positions might have done so by conforming to 'male' working patterns, contracting out their childcare obligations to other women, who remain as underpaid and undervalued as ever. Similarly, the increase in numbers of women doing certain types of jobs might coincide with a decrease in the pay or status of the job in question. In the US, school desegregation, while appearing to achieve racial integration, in fact frequently replicated racial hierarchies within schools, as reflected in the fact that the racial achievement gap persists even in racially mixed middle class schools. ${ }^{49}$ Thus quantifiable change might only partially reflect qualitative change. There is a danger too that a focus on equality of results pays too little attention to the equally important duty to accommodate diversity by adapting existing structures. This is particularly problematic in relation to disparate impact or indirect discrimination because of the possibility of a justification defence. Under the US standard, a practice which excludes a protected group is only prohibited if, in the words of Burger CJ in Griggs, it 'cannot be shown to be related to job performance. ${ }^{50}$ Similarly, the UK provision permits an employer to justify prima facie indirect discrimination if it is a proportionate means of achieving a legitimate aim. ${ }^{51}$ Ultimately, therefore, if an employer can justify disparate impact on the basis that it is proportional to a legitimate end inequality of results is condoned. Thus equality of results, while providing a welcome antidote to equality of treatment, can be seen to be at best a partial framework for situating the right to equality. There is the additional need for structural change.

\section{Equality of Opportunity}

Equality of opportunity is a popular alternative to both equal treatment and equality of results and is given statutory force in several jurisdictions. ${ }^{52}$ Proponents of this view recognize that equal treatment against a background of past and structural discrimination can perpetuate

\footnotetext{
${ }^{49}$ MinOw, supra note 7, at 26.

${ }^{50}$ Griggs, supra note 44 , at 431.

${ }^{51}$ Equality Act 2010 (UK), s 19.

${ }^{52} I d$ at section 149.
} 
disadvantage. Using the graphic metaphor of competitors in a race, it is argued that true equality cannot be achieved if individuals begin the race from different starting points. However, according to this approach, to focus entirely on equality of results is to go too far in subordinating the right to individual treatment to a utilitarian emphasis on outcomes. Once individuals enjoy equality of opportunity, the problem of institutional discrimination has been overcome, and fairness demands that they be treated on the basis of their individual qualities, without regard to sex or race. This model therefore specifically rejects policies which aim to correct imbalances in the workforce by quotas or targets the aim of which is one of equality of outcome. Instead, an equal opportunities approach aims to equalize the starting point rather than the end result. Once all have equal opportunities, they should be judged on individual merit. Equality of opportunity is fully compatible with unequal results, not just because individual talent differs, but because this approach incorporates and emphasises choice. Once opportunities are made available, each individual can choose her own life course.

Like equality of results, equality of opportunity requires more attention to be given to what counts as an opportunity, and ultimately, what counts as equality. What measures are required to ensure that individuals are genuinely able to compete equally? Williams distinguishes between a procedural and a substantive sense of equal opportunities. On a procedural view, equality of opportunity requires the removal of obstacles to the advancement of women or minorities, but does not guarantee that this will lead to greater substantive fairness in the result. ${ }^{53}$ For example, the abolition of word-of-mouth recruitment or non-job-related selection criteria removes procedural obstacles and so opens up more opportunities. But this does not guarantee that more women or minorities will in fact be in a position to take advantage of those opportunities. Those who lack the requisite qualifications as a result of past discrimination will still be unable to meet job-related criteria; women with childcare responsibilities will still not find it easier to take on paid work. In the famous words of US President Lyndon Johnson, it is 'not enough to open the gates of opportunity. All our citizens must have the ability to walk through those gates. ${ }^{54}$

\footnotetext{
${ }^{53}$ BERNARD WILLIAMS, The Idea of Equality, in PHILOSOPHY, POLITICAL AND SOCIETY SECOND SERIES 110 (Peter Laslett and W G Runciman eds., 1965).

${ }^{54}$ Lyndon B Johnson, Address at Howard University (4 June 1965) cited in Abagail Thernstrom, Voting Rights, Another Affirmative Action Mess, 43 U.C.L.A. L. REV. 2031, fn 22 (1996).
} 
A substantive sense of equality of opportunity, by contrast, requires measures to be taken to ensure that persons from all sections of society have a genuinely equal chance of satisfying the criteria for access to a particular social good. ${ }^{55}$ This requires positive measures such as education and training, and family-friendly measures. It may go even further, and challenge the criteria for access, since existing criteria of merit may themselves reflect and reinforce existing patterns of disadvantage. For example, criteria which stress a continuous work history would reflect a view that experience out of the paid labour force is of little value to a future job. Women who have left the paid workforce to bring up children would thereby be subject to detriment. As Hepple argues, one is not supplying genuine equality of opportunity if one applies an unchallenged criterion of merit to people who have been deprived of the opportunity to acquire 'merit' ${ }^{56}$ In practice, however, equality of opportunity is rarely used in its substantive sense when framing equality laws. Thus equality of opportunity, like equality of results, remains at most a partial basis for grounding the right to equality.

\section{Dignity}

Rather than refocusing on equality of opportunity or results, many legislatures, courts and theorists have searched for a more substantive core to the notion of equality. Some such substantive core could, in particular, avert the 'levelling down' argument. This can be seen in the US Supreme Court case of Johnson v California, which involved racial segregation of prisoners. ${ }^{57}$ The prison authority argued that this should not be regarded as discriminatory because all races were 'equally segregated'. The US Supreme Court emphatically rejected the argument that equality could be satisfied by 'neutrality' of this sort. Citing the earlier case of Powers $v$ Ohio, the Court stated: 'It is axiomatic that racial classifications do not become legitimate on the assumption that all persons suffer them in equal degree.' 58

\footnotetext{
${ }^{55}$ WILLIAMS, supra note 53, at 125-6.

${ }^{56}$ Bob Hepple, Discrimination and Equality of Opportunity - Northern Irish Lessons (1990) 10 OXFORD J of LEGAL STUDIES. 408, 411 (1990).

${ }^{57}$ Johnson v California, 543 U.S. 499 (2005), (US Supreme Court).

${ }^{58}$ Powers v Ohio, 499 US 400, 410 (1991), (US Supreme Court).
} 
The US Supreme Court did not specify the core value it was referring to. Other jurisdictions have been more explicit. The foremost candidate has been the notion of dignity. The primacy of individual dignity and worth as a foundation for equality rights has been clearly articulated in a number of jurisdictions, both in constitutional or statutory documents and by courts. Particularly vocal in this regard has been the Supreme Court of Canada, which has located dignity at the centre of the equality principle. 'Equality means that our society cannot tolerate legislative distinctions that treat certain people as second class citizens, that demean them, that treat them as less capable for no good reason, or that otherwise offend fundamental human dignity. ${ }^{59}$, Similarly, from the very beginning of the jurisprudence on equality in the South African Constitutional Court, dignity has played a central role. Thus Ackerman J in the early case of Prinsloo $v$ Van der Linde, ${ }^{60}$ stated that unfair discrimination 'principally means treating persons differently in a way which impairs their fundamental dignity as human beings'.

Certainly, there is much that makes dignity an intuitively appealing concept. ${ }^{61}$ Most importantly, dignity should replace rationality as a trigger for the equality right. Rationality has proved to be an exclusive doctrine, which has been deployed to deny access to the equality right; in particular to women, who were portrayed as lacking the prerequisite rationality. ${ }^{62}$ The crucial advance represented by substituting dignity for rationality is that dignity is seen to be inherent in the humanity of all people.

However, a closer look at these formulations reveals that dignity is not the panacea it is often imagined to be. Dignity on its own does not inevitably entail equality. Indeed, dignity is just as capable of being hierarchical. Once could easily imagine that some could be regarded as more dignified than others. We could regard everyone as having moral worth, without inevitably regarding them as having equal moral worth, and therefore as attracting equal concern and respect. Indeed, the history of the concept of dignity reveals its roots in ideas of rank and hierarchy rather than equality. ${ }^{63}$ It is only by insisting that everyone has equal moral

\footnotetext{
${ }^{59}$ Law, supra note 4 at para 51.

${ }^{60}$ Prinsloo supra note 5 at para 31.

${ }^{61}$ For a particularly persuasive approach, see Denise Réaume, Discrimination and Dignity, 63 LA. L. REV. 645 (2002-2003).

${ }^{62}$ FREDMAN, WOMEN AND THE LAW, supra note 39 at Chapter 1.
} 
worth that we achieve the goal of justifying equal concern and respect. This demonstrates that equality plays an independent role, over and above dignity. In fact, we are still asking the question: equality of what? And our answer in this case is 'equal dignity'.

In any event, 'dignity' is open to different interpretations, and even opposite results. ${ }^{64}$ This can be seen in the South African Constitutional Court case of Hugo. ${ }^{65}$ The case concerned the pardon issued by President Mandela to all women prisoners who were mothers of young children. The pardon was challenged by a male prisoner, the sole carer of his young children, on the basis that it discriminated on grounds of gender. The court rejected the case.

According to Goldstone J, 'The Presidential Act might have denied fathers an opportunity it afforded mothers, but it could not be said to have fundamentally impaired their rights of dignity or sense of equal worth. ${ }^{96}$ By contrast, for Kriegler J, it was the assumption that women are the primary child-carers which constituted an assault on their dignity. As he put it in his dissent: 'One of the ways in which one accords equal dignity and respect to persons is by seeking to protect the basic choices they make about their own identities. Reliance on the generalisation that women are the primary care givers is harmful in its tendency to cramp and stunt the efforts of both men and women to form their identities freely . . . ${ }^{67}$ Here dignity is interpreted in at least three ways: as protecting a sense of self - worth, as protecting basic choices individuals make, and as protecting individuals against harmful stereotypes. There is no particular reason within the conception of dignity why we should choose any particular one of these formulations.

The use of dignity in the application of the right to equality has in practice been highly problematic. ${ }^{68}$ Courts in several jurisdictions have tended to regard dignity as an independent

\footnotetext{
${ }^{63}$ Stephanie Hennette-Vauchez, A human dignitas? Remnants of the ancient legal concept in contemporary dignity jurisprudence, 9 I.C.O.N. 32 (2011); Christopher McCrudden, Human dignity and judicial interpretation of human rights, 19(4) E.J.I.L.656 (2008).

${ }^{64}$ See David Feldman, Human Dignity as a Legal Value: Part 1 (Winter) P.L. 682 (1999); McCrudden, supra note 63 .

${ }^{65}$ President of the Republic of South Africa v Hugo (CCT11/96), [1997] ZACC 4, (South African Constitutional Court).

${ }^{66} I d$. at para 47.

${ }^{67}$ Id. at para 80 .

${ }^{68}$ Albertyn and Goldblatt, supra note 12.
} 
element in discrimination law, requiring a claimant to prove not just that she has been disadvantaged, but that this signifies lack of respect of her as a person. We have already seen that in the South African case of Hugo, ${ }^{69}$ the Court held that even though the applicant had been denied an opportunity made available to women, this could not be said to have impaired his fundamental sense of dignity or self-worth. This danger has been similarly demonstrated in the Supreme Court of Canada, in which the court held that proof of disadvantage on grounds of an enumerated characteristic would not in itself be discriminatory if the claimant could not prove in addition that this disadvantage signified that society regarded her of less value than others. ${ }^{70}$ Thus in Gosselin, ${ }^{71}$ welfare beneficiaries under 30 received significantly lower benefit than those over 30 unless they participated in a designated work activity or education programme. Given the considerable shortfall in places available, many young people, including the claimant, experienced real poverty. She claimed that this constituted age discrimination, in breach of the equality guarantee in section 15(1) of the Canadian Charter. However, the majority held that 'the provision of different initial amounts of monetary support to each of the two groups does not indicate that one group's dignity was prized above the other's' ${ }^{72}$ It therefore rejected her claim. In a remarkably similar response, in the House of Lords in the UK case of Reynolds, Lord Rodgers stated: 'There is no doubt that the relevant regulations, endorsed by Parliament, deliberately gave less to those under 25 . But this was not because the policymakers were treating people under 25 years of age as less valuable members of society. ${ }^{, 73}$

This problem has now been recognized by the Canadian Court. In an important case in 2010, $R v$ Kapp,${ }^{74}$ it acknowledged that 'several difficulties have arisen from the attempt . . to employ human dignity as a legal test. There can be no doubt that human dignity is an essential value underlying the s. 15 equality guarantee. In fact, the protection of all of the rights guaranteed by the Charter has as its lodestar the promotion of human dignity. . . . But

\footnotetext{
${ }^{69}$ President of the Republic of South Africa v Hugo, (CCT11/96) (South African Constitutional Court).

${ }^{70}$ Law, supra note 4; Gosselin v Quebec, [2002] 4 S.C.R. 429 (Canadian Supreme Court).

${ }^{71} I d$.

${ }^{72} I d$. at para 61.

73 [2005] UKHL 37at para 45.

${ }^{74}$ R. v. Kapp, [2008] 2 S.C.R. 483 (Canadian Supreme Court).
} 
as critics have pointed out, human dignity is an abstract and subjective notion that . . has ... proven to be an additional burden on equality claimants, rather than the philosophical enhancement it was intended to be. ${ }^{75}$ This strongly suggests that the right to equality cannot simply be collapsed into the right to dignity.

\section{Part IV Substantive Equality: A Four-Dimensional Concept}

In this section, I draw on the insights above to reconceptualise the right to equality by stipulating a four dimensional framework of aims and objectives. Firstly, the right to substantive equality should aim to redress disadvantage. Secondly, it should counter prejudice, stigma, stereotyping, humiliation and violence based on a protected characteristic. Thirdly, it should enhance voice and participation, countering both political and social exclusion. Finally, it should accommodate difference and achieve structural change.

The four dimensional approach extrapolates from existing understandings of the right to substantive equality. The first two dimensions, disadvantage and stigma or stereotyping, are clearly evident in Canadian and South African jurisprudence. The Supreme Court of Canada summed up its position in its 2011 case of Withler ${ }^{76}$ Referring to substantive equality as the 'animating norm'77 of the right to equality in the Charter, the court stated that, in determining whether substantive equality had been violated, the question should be whether 'having regard to all relevant factors, the impugned measure perpetuates disadvantage or stereotypes the plaintiff group. ${ }^{78}$ Similarly, in the early South African Constitutional Court case of Brink $v$ Kitshoff $f^{79}$, O'Regan J, writing for the Court, identified the purpose of the constitutional right to equality as remedying patterns of disadvantage. In subsequent cases, the court effectively placed dignity at the centre of the equality right. However, neither of these jurisdictions has expressly articulated the relationship between dignity and disadvantage, or how tensions between them should be addressed. The participation dimension has been

\footnotetext{
${ }^{75} I d$. at paras $21-2$.

${ }^{76}$ Withler v. Canada (Attorney General), [2011] 1 S.C.R. 396 (Canadian Supreme Court).

${ }^{77} I d$. at para 2.

${ }^{78} I d$. at para 3.

${ }^{79}$ Brink v Kitshoff (CCT15/95), [1996] ZACC 9 at para 42, (South African Constitutional Court).
} 
central to the US court's development of race jurisprudence based on exclusion from the political process of 'discrete and insular minorities ${ }^{90}$, and resonates too with the concern of the Canadian and South African courts with permanent residents as non-citizens. ${ }^{81}$ The transformative dimension grows out of and elaborates duties of accommodation in relation to religion and disability in the US, Canada and the UK, ${ }^{82}$ and the UK duty to have due regard to the need to advance equality of opportunity. ${ }^{83}$ As argued above, the four dimensional framework is rooted in existing understandings, extrapolating from what is already implicit in the approaches to substantive equality of courts and other national and international decisionmakers. By drawing these implicit understandings together into a multi-dimensional format, it is argued, the resulting synthesis takes forward the approach to substantive equality in ways that can be more responsive to real social wrongs.

One of the benefits of a multi-dimensional approach to substantive equality is that it allows us to address the interaction between different facets of inequality. Philosophers and political scientists tend to focus on distributive inequality, ${ }^{84}$ while discrimination lawyers see the right to equality as primarily concerned with countering prejudice and stereotyping, regarding distributive inequalities as the domain of policy-makers. ${ }^{85}$ It is argued here that both have an importance within the right to equality, but these do not exhaust the field. It is important too to include inequalities in participation, and structural obstacles to equality. Moreover, the ways in which they interact need to be understood and addressed. These interactions are not always harmonious. But instead of excluding one or the other facet wholly from the right to equality, it is argued here that a substantive approach requires them to be considered together. This makes it possible too to recognise and deal with conflicts between the different facets. Where there is the potential for these facets to pull in opposite directions, the aim is to look for synthesis or compromise, rather than suggesting that substantive equality pursue one of

\footnotetext{
${ }^{80}$ Carolene Products Co., supra note 26.

${ }^{81}$ Andrews v. Law Society of British Columbia, [1989] 1 SCR 143, (Canadian Supreme Court); Khosa and Mahlaule v Minister for Social Development, (CCT13/03), (South African Constitutional Court).

${ }^{82}$ US Airways v. Barnett 535 U.S. 391 (2002), (US Supreme Court); Multani v. Commission Scolaire Marguerite v.Bourgeoys, [2006] 1 S.C.R. 256, (Canadian Supreme Court).

${ }^{83}$ Equality Act 2010 (UK), s.149.

${ }^{84}$ Raz supra note 34 at 3.

${ }^{85}$ See further Sandra Fredman, Redistribution and Recognition: Reconciling Inequalities, 23 S.A.J.H.R. 214 (2007).
} 
the aims at the cost of obliterating the others. The four dimensional approach is therefore not a definition as such, but an analytic framework which can be used to assess and assist in modifying policies and practices to better achieve substantive equality. Drawing attention to all the dimensions and insisting on resolving conflicts and building complementarities can move us positively towards ensuring that laws, policies or programmes can be formulated in ways which further substantive equality.

The next section briefly explains each dimension while the following section elaborates briefly on how the dimensions complement and buttress each other, and how conflicts may be resolved. Given limits of space, this paper does not examine the extent to which existing legal formulations of the right to equality or anti-discrimination conform to the principle of substantive equality outlined here; this has been done elsewhere. ${ }^{86}$ Nor does this paper deal with the extent to which the right to substantive equality can be justifiably limited by reference to other rights or the public interest; the argument being that the right itself should be clearly established before it is balanced against other rights or interests.

\section{Redressing disadvantage}

One of the key advances represented by substantive equality over formal equality, is that it is expressly asymmetric. This sets it apart from the equal treatment model, which prohibits classification on the prohibited grounds regardless of whether this favours or disfavours a disadvantaged group. Instead, substantive equality focuses on the group which has suffered disadvantage: women rather than men, black people rather than whites, people with disabilities rather than able-bodied, or gay people, rather than heterosexuals. Women, ethnic minorities, black people, and disabled people tend to be amongst the lowest earners, to experience the highest rates of unemployment, and to predominate among those living in poverty or social exclusion. Thus it is not so much an individual's status or group identity which is the problem, but the detrimental consequences attached to that status. In effect then, this dimension of substantive equality bridges the gap between the traditional sphere of antidiscrimination law and distributive equality, which the latter, as we have seen, has been regarded as falling within the terrain of policy rather than human rights law.

\footnotetext{
${ }^{86}$ FREDMAN, DISCRIMINATION LAW, supra note 8 at Chapter 4.
} 
Targeting disadvantage rather than aiming at neutrality has several advantages. Most importantly, it removes the possibility of a levelling down option. Its asymmetry also means that it is possible to reconcile affirmative action with the right to equality. Although apparently breaching the principle of equal treatment, affirmative action in reality advances substantive equality by taking steps to redress the disadvantage. This is a sounder basis for supporting affirmative action than equality of results. It does not require results to be numerically equal in order to lessen disadvantage. Instead, it leaves open the question as to when disadvantage has been redressed. Indeed, it is compatible with a prioritarian theory.

However, focusing on disadvantage also carries with it some important challenges. One is to specify the nature of disadvantage. In this context, disadvantage is primarily aimed at socioeconomic disadvantage, and the right to equality frequently operates to address underrepresentation in jobs, under-payment for work of equal value, or limitations on access to credit, property, or similar resources. However, disadvantage should encompass more than maldistribution of resources. It needs also to take on board the constraints which power structures impose on individuals because of their status. Young argues that instead of focusing on the allocation of material, the focus should be on domination, or structures which exclude people from participating in determining their actions. ${ }^{87}$ Crucially, domination need not be attributable to the actions of any particular individual, but produces constraints which are the intended or unintended product of actions of many people. ${ }^{88}$ This is particularly salient in relation to women. Women's disadvantage cannot be characterised solely in terms of income poverty, but is centrally related to imbalances of power within and outside the family. ${ }^{89}$ For example, as Chant notes, household income may bear no relation to women's poverty because women may not be able to access it. ${ }^{90}$

Disadvantage can also be understood as a deprivation of genuine opportunities to pursue one's own valued choices. This draws on the insights of the 'capabilities' theory developed

\footnotetext{
${ }^{87}$ IRIS YounG, JUSTICE AND THE POLITICS OF DifFERENCE (1990)

${ }^{88} \mathrm{Id}$, at 31-2; MacKinnon supra note 49 at 572.

${ }^{89}$ Sylvia Chant, The 'Feminisation of Poverty' and the 'Feminisation' of Anti-Poverty Programmes: Room for Revision?, 43 J. DEV. S. 165, 174 (2008).

${ }^{90}$ Sylvia Chant, Rethinking the Feminisation of Poverty, 7(2) J. of DEV. AND CAP. 201, 208 (2006).
} 
by Amartya Sen ${ }^{91}$ and Martha Nussbaum. ${ }^{92}$ Starting from the premise that each individual should be able to be and do what she values, this theory stresses the importance of considering the extent to which people are actually able to exercise their choices, rather than simply having the formal right to do so. The capabilities approach is richer than equality of opportunity, because it incorporates both individual autonomy and the differing needs of differently situated individuals. It recognises that it may not be feasible for a person to achieve the goals she values due to social, economic, or physical constraints, as well as due to political interference. ${ }^{93}$ 'What people can achieve is influenced by economic opportunities, political liberties, social powers and the enabling conditions of good health, basic education, and the encouragement and cultivation of initiatives. ${ }^{94}$ Thus it is not enough to treat everyone equally, since the same treatment of individuals with very different constraints can replicate disadvantage. One of the functions of the right to substantive equality is therefore to redress disadvantage by removing obstacles to genuine choice.

At the same time, it needs to be recognised that choice itself can be problematic, since people often adapt their choices to their circumstances. For example, women might prefer part-time work even if it is insecure and low paid, because it permits them to combine paid work and child-care. But this choice is made within a context in which women are assumed to be the primary child-carers. The fact that women make these choices should not imply that there is no further need for legal intervention. Substantive equality should aim to remove the disadvantages attached to part-time work. Moreover, there are circumstances in which the concern is not solely to increase the range of feasible options but to address the disadvantage attached to the circumstances a person actually finds herself in. This is particularly true in the context of some kinds of disability; as well as of caring obligations. These complexities within the notion of disadvantage suggest that more is needed than simply this dimension of substantive equality. Redressing disadvantage needs to be augmented by the second dimension (addressing stigma, prejudice and stereotyping), to which we now turn.

\footnotetext{
${ }^{91}$ AMARTYA SEN, DEVELOPMENT AS FREEDOM (1999).

92 MARTHA NUSSBAUM, WOMEN AND HUMAN DEVELOPMENT (2000).

${ }^{93} I d$. at $90-1$.

${ }^{94}$ SEN, supra note 91 , at 5.
} 


\section{Redressing stigma, stereotyping and humiliation}

Stigma, stereotyping, humiliation, and violence on grounds of gender, race, disability, sexual orientation, or other status can be experienced regardless of relative disadvantage. This is the dimension of equality which speaks to our basic humanity. Equality attaches to all individuals, not because of their merit, or their rationality, or their citizenship or membership of any particular group, but because of their humanity. Individuals should not be humiliated or degraded through racism, sexism, violence, or other status-based prejudice.

This dimension has similarities to 'dignity' but attempts to avoid some of its pitfalls. Rather than relying on a vague and manipulable definition of dignity, I prefer the concept of 'recognition', originally developed by Hegel, and refined and expanded by Fraser and Honneth ${ }^{95}$. Recognition refers to the central importance of inter-personal affirmation to our sense of who we are. Identity is shaped through the ways in which others recognize us, and we recognize others. Misrecognition or recognition inequalities arise through denigration, humiliation, and failure to value individuals. To that extent recognition resonates with the dignity discourse. However, recognition and dignity differ because of the former's essentially relational format: rather than regarding each person as an isolated individual to whom dignity is attached, it regards individuals as constructed in many ways by society and social norms. Substantive equality is therefore capable of addressing race and gender as social constructs. Instead of regarding sex as a biological given, the right to equality aims to address its social consequences through its focus on the ways in which people relate to each other. Thus the right to equality can address sexual harassment and stereotyping in ways in which a pure equal treatment paradigm could not. A similar approach can be taken to disability: using the recognition dimension of substantive equality, it is possible to address the social implications of disability rather than focussing on the impairment.

The pivotal importance of this dimension can be seen in Brown v Board of Education. ${ }^{96}$ The US Supreme Court posed the question thus: 'Does segregation of children in public schools solely on the basis of race, even though the physical facilities and other "tangible" factors may be equal, deprive the children of the minority group of equal educational

\footnotetext{
95 NANCY FRASER \& ALEX HONNETH, REDISTRIBUTION OR RECOGNITION (2003).

${ }^{96}$ Brown v Board of Education, 347 US 428 (1954) (US Supreme Court).
} 
opportunities?'97 The answer was unequivocally in the affirmative. And the reason given was strikingly resonant of recognition issues: 'To separate them from others of similar age and qualifications solely because of their race generates a feeling of inferiority as to their status in the community that may affect their hearts and minds in a way unlikely ever to be undone.'98 The recognition principle also addresses racist, sexist, homophobic and other violence against protected groups. Such violence is distinctive in its negation of the very identity of the victim.

\section{The participative dimension: social inclusion and political voice}

The third dimension of substantive equality relates to participation. The right to equality is concerned with two aspects of participation. The first is political. Given that past discrimination or other social mechanisms have blocked the avenues for political participation by particular minorities, equality laws are needed both to compensate for this absence of political voice and to open up the channels for greater participation in the future. In one of the most famous footnotes in history, the US Supreme Court stated that judicial intervention under the equality guarantee was particularly necessary because of the way in which 'prejudice against discrete and insular minorities . . . tends seriously to curtail the operation of those political processes ordinarily to be relied upon to protect minorities' ${ }^{99}$ Building on this approach, John Hart Ely developed his 'representation-reinforcing' theory of judicial review in relation to groups 'to whose needs and wishes elected officials have no apparent interest in attending'. ${ }^{100}$ Similarly, the Supreme Court of Canada in Andrews v Law Society ${ }^{101}$ held that the equality guarantee should extend to non-citizens for the very reason that, lacking in political power, they were vulnerable to having their interests overlooked and their rights to equal concern and respect violated. These formulations address the lack of political voice by affording excluded groups judicial review through the right to equality. A

\footnotetext{
${ }^{97} I d$. at 493 .

${ }^{98} I d$. at 494 .

${ }^{99}$ Carolene Products Co, supra note 26, at 152 n 4 (per Stone J).

100 JOHN HART ELY DEMOCRACY AND DISTRUST: A THEORY OF JUDICIAL REVIEW 46 (1980).

${ }^{101}$ Andrews, supra note 8.
} 
further step might involve opening up avenues for greater political participation, potentially through quotas in Parliament, or other explicit measures to achieve parity. ${ }^{102}$

The second aspect of the participative dimension is to address the importance of community in the life of individuals. Rather than the universal, abstract individual of formal equality, substantive equality recognizes that individuals are essentially social. To be fully human includes the ability to participate on equal terms in community and society more generally. Fraser puts particular emphasis on participation, regarding parity of participation as the normative core of her conception of justice, encompassing both redistribution and recognition without reducing either one to the other. ${ }^{103}$ Collins, in searching for a justification for departure from the equal treatment principle, develops the concept of social inclusion as central to his notion of substantive equality. Like Young and Fraser, Collins's conception includes but goes beyond distribution of material goods. 'Although . . . social inclusion shares with equality a concern with the distributive allocations to groups and individuals in a society, its more fundamental objective is the outcome of social cohesion. Social inclusion is a theory of how society can be integrated and harmonious. At its simplest, the theory is that if everyone participates fully in society, they are less likely to become alienated from the community and will conform to its social rules and laws. ${ }^{104}{ }^{\prime} \mathrm{He}$ sees the goal of social inclusion as having the potential to provide a vital ingredient in a more coherent account of the aims of anti-discrimination law. A further alternative characterization is that of solidarity, a value which is also expressed in the EU Charter of Fundamental Rights. Barnard argues that solidarity requires not just the removal of obstacles to participation, but also active measures to integrate individuals into society. ${ }^{105}$ It is noteworthy that social cohesion is expressly required in UK anti-discrimination law. The EA 2010 requires public bodies to have due regard to the need for good race relations. ${ }^{106}$

\footnotetext{
102 See Ruth Rubio Marin, A new European Parity-Democracy Sex Equality Model and Why it Won't Fly in the United States, 60 AM. J OF COMP. L. 99-126 (2012).

${ }^{103}$ FRASER \& HONNETH, supra note 95 , at 36-7.

${ }^{104}$ Collins, supra note 11 , at 24 .

${ }^{105}$ C. Barnard, The Future of Equality Law: Equality and Beyond in THE FUTURE OF LABOUR LAW: LIBER AMICORUM SIR BOB HEPPLE 213 - 228 (C. Barnard, et al. eds., 2004).

${ }^{106}$ Equality Act 2010 (UK), s.149.
} 


\section{Accommodating difference and structural change}

Under a formal equality or 'anti-classification' approach, gender, race, ethnicity, or other status are regarded as irrelevant. This presupposes that it is both desirable and possible to abstract an individual from these aspects of her identity and treat her entirely on 'merit'. By contrast, substantive equality recognizes that these characteristics can be valued aspects of an individual's identity. The problem is not so much difference per se, but the detriment which is attached to difference. The fourth aim of substantive equality should therefore be to respect and accommodate difference, removing the detriment but not the difference itself. This in turn means that existing social structures must be changed to accommodate difference, rather than requiring members of out-groups to conform to the dominant norm. Substantive equality is therefore potentially transformative. For example, working hours have always been patterned on the assumption that childcare takes place outside the labour market. Women who wish to participate in the paid labour market must conform to this paradigm, either by forgoing having children, or leaving their children with paid child-carers or family members. Substantive equality aims to change such institutions so that participative parenting is possible for both mothers and fathers in the labour market. Similarly, the built environment must be adapted to accommodate the needs of disabled people, and dress codes and holidays must accommodate ethnic and religious minorities.

As with the other facets of substantive equality, structural change raises challenges. Firstly, does accommodating difference require general structural change, or is it sufficient to create exceptions for individuals, while maintaining the general rule? An 'exceptionalist' approach has attracted criticism on the basis that, as Brodsky and Day have argued, 'it does not challenge the imbalances of power, or the discourses of dominance, such as racism, ablebodyism and sexism, which result in a society being designed well for some and not for others. It allows those who consider themselves 'normal' to continue to construct institutions and relations in their image, as long as others, when they challenge this construction are 'accommodated' ... In short, accommodation is assimilationist. Its goal is to try to make 'different' people fit into existing systems. ${ }^{107}$ However, the dichotomy between exceptionalism and structural change might be overstated. There are clearly situations, particularly in the context of gender discrimination, in which the norm should be changed.

\footnotetext{
${ }^{107}$ Shelagh Day and Gwen Brodsky, The Duty to Accommodate: Who Will Benefit?, 75 CAN. BAR REV. 433, 447-457 (1996).
} 
But in other situations it might be appropriate to retain the norm as a whole, but with specific exceptions to cater for religious differences. For example, if Sikhs are unable to wear a hard hat on a construction site because of their religious duty to wear a turban, the creation of an exception is preferable to the wholesale rejection of the rule.

The second challenge arises from the fact that structural change can be costly. How can we justify expecting the State or private bodies to bear the cost? One way of answering this question could be on the basis of a tort-type model, namely that only those at fault for causing the damage should be responsible for compensating the victim. However, a basic premise of substantive equality is that it can respond to structural barriers, for which no single perpetrator can be found. Rather than look for a perpetrator 'at fault,' the costs should be borne by those in a position to bring about change. This also avoids an adversarial approach, which might invite defensive rather than co-operative action. Kelman argues that the decision as to where costs should fall depends on the nature of those costs. He contrasts 'simple discrimination,' which is similar to the equal treatment principle, with the demand for accommodation. Because 'simple discrimination' can be removed by a change in subjective taste or conduct, all claims to be free of simple discrimination can be vindicated. ${ }^{108}$ A claim for simple discrimination therefore cannot be balanced against other competing claims. The demand for accommodation, by contrast, is a claim on social resources which are inherently finite and therefore need to be balanced against other demands. ${ }^{109}$ Thus, he argues, claims to accommodation are always subject to the argument that they are unreasonable in the sense that the resources devoted to them could be spent better. ${ }^{110}$

This does not, however, give any guidance as to what is reasonable. Kelman generally approaches this question from the perspective of market-based decision-making. From the perspective of substantive equality, the starting point must lie in the recognition that the question is not about how much to spend, but who should bear the cost. It is misleading to argue that it is too costly to accommodate difference or to bring about structural change, since the cost is incurred in any event. The status quo, without legal intervention, requires the outgroup to bear the full cost: women bear the cost of child-bearing and childcare; disabled

\footnotetext{
${ }^{108}$ M Kelman, 'Market Discrimination and Groups' (2001) 53 Stanford Law Review 833 .

${ }^{109}$ ibid. at 853-854.

${ }^{110} I d$ at 837.
} 
people bear the cost of disability; and ethnic minorities bear the cost of their own cultural or religious commitments. Whatever cost is not borne by employers or the State is left on the shoulders of those who are least able to bear it. At the same time, little notice is taken of the fact that society does bear the cost of the specific characteristics of dominant groups, be they male, able-bodied, or in the ethnic majority. Working time, the built environment, or religious or cultural holidays and dress already cater for the dominant groups. Substantive equality aims to redistribute these costs in ways which are fairer to all. Ultimately, then, any decision as to cost allocation should be assessed against the framework of the four dimensions.

\section{A multi-dimensional approach: complementarities and conflicts}

Having considered each of the dimensions and the challenges they raise, what does a multidimensional approach have to offer? This section aims to sketch how the dimensions can be used to buttress one another and better address the weaknesses of each. We have already seen that focusing only on redressing disadvantage, or the first dimension, is not sufficient to deal with the need to value individuals regardless of their socio-economic position. The need for a multi-dimensional approach is reinforced by considering three further questions. The first concerns the link between disadvantage and 'grounds of discrimination' or protected characteristics. If we were to maintain that the primary concern is with socio-economic disadvantage, why do we not simply focus on disadvantage, regardless of its connection with gender or other out-groups? This question can only be helpfully answered by recognising the multi-dimensional nature of substantive equality, which addresses disadvantage as part of a pattern of stigma and prejudice, structural barriers and exclusion. When disadvantage is disproportionately associated with a group which also suffers from one or all of the other factors, it should attract the attention of the right to equality. This also helps answer the question of whether socio-economic disadvantage should be a ground for discrimination. Socio-economic disadvantage per se should be addressed through other legal rights and policies, such as the right to social security. The right to equality applies to socio-economic disadvantage when such disadvantage is also associated the other dimensions, such as stigma, lack of voice, or structural factors which lock individuals and their families into a cycle of disadvantage. ${ }^{111}$

${ }^{111} I d$. 
The second reason why redressing disadvantage cannot be the sole dimension of substantive equality arises in response to the earlier critique of indirect discrimination. This dimension supports indirect discrimination in that equal treatment can breach the right to inequality where it reinforces disadvantage. However, it does not address the role of business-related justifications, noted above. Instead, redressing disadvantage needs to be allied with the fourth dimension, which requires structural change. The right to substantive equality would not be satisfied by a conception of indirect discrimination which permits business-related justifications without more: it would also require change to enable the excluded group to meet the job criteria better. This might include supply side changes such as training or childcare, or demand side changes such as flexible hours. Equally, paying attention to the fourth dimension emphasises the importance of positive duties on employers and other to take preemptive action to avoid disparate impact. This has been recognised in several jurisdictions which require proof that there are no ways of achieving the respondent's purpose which have a less invasive discriminatory impact. ${ }^{112}$

Thirdly, redressing disadvantage does not sufficiently address under-representation in political decision-making. Unlike under-representativeness in employment or education, it is difficult to characterise under-representation in decision-making in terms of a maldistribution of benefits. Including the participative dimension requires us to ask a different question, namely, what would constitute participation for the purpose of substantive equality? This recognises that it is not so much about the need to distribute benefits as the need to ensure that the perspectives of women and others are heard and taken seriously. This also sheds light on whether equality means strict numerical parity or not.

Similarly, it would be a mistake to see the second dimension (stigma, stereotyping, prejudice and violence) as standing alone. This can be seen by looking again at the judgment in Brown $v$ Board of Education. Although the case was based on the stigma and feeling of inferiority generated by segregated education, this should not be separated from the reality of disadvantage and the need for structural change in racially segregated education in America. As Martha Minow asks, 'Did the Court in Brown find racially separate education inherently unequal because it tended to be educationally inferior, or because segregated education communicated and reinforced racial hierarchy? The Court did not sort out these two

\footnotetext{
${ }^{112}$ See further FREDMAN, DISCRIMINATION LAW, supra note 8.
} 
options.' ${ }^{113}$ As the aftermath of Brown demonstrates, simply addressing recognition harms without paying serious attention to redressing disadvantage and, structural change, such as improving the quality of educational provision, is unlikely to achieve substantive equality.

Stigma and stereotyping can of course lead directly to material disadvantage, as seen in the South African case of Union of Refugee Women, where a prohibition on refugees working in the private security industry was challenged as a breach of the right to equality in Section 9 of the Constitution. The government argued that refugees could not be regarded as reliable, an assertion which the minority judges held to be unfairly prejudicial and stereotyping. As O'Regan and Mokgoro JJ put it in their dissenting judgments: 'By excluding all refugees whether or not they can comply with the requirements of section 23(1)(d), the clear message underlying section 23(1)(a) is that whether refugees can prove their trustworthiness or not, they may not be employed as security service providers.' ${ }^{114}$ However, 'it is not only the social stigma which may result from such discrimination, but also the material impact that it may have on refugees.' 115

The multi-dimensional approach also flushes out potential conflicts between dimensions. Rather than rendering one aspect of the conflict invisible and therefore effectively permitting one to trump the other, the multi-dimensional approach requires synthesis and compromise. This can be seen by considering a major challenge raised by the fourth dimension, the need to accommodate difference and achieve structural change. At what point is it unreasonable or even wrong to accommodate difference, or tolerate minority cultures? Many of these dilemmas arise in respect of religion. Should polygamy be accommodated? Should religious objections to equal rights for LGBT or women be tolerated? Should burkas be permitted? Female genital mutilation? How does this compare with minority approaches to religious festivals, dietary laws, ritual slaughter of animals? Here again, resolution of these difficult dilemmas is facilitated by the multi-faceted approach to equality. Thus the transformative dimension must coexist with the second dimension, which addresses stigma, prejudice, stereotyping and violence. Practices which compromise the basic dignity and humanity of individuals cannot be acceptable in order to accommodate difference. Sexism, racism, and

\footnotetext{
${ }^{113}$ MiNOW, supra note 7, at 20.

${ }^{114}$ Union of Refugee Women v. Director, Private Security Industry Regulatory Authority (CCT 39/06) [2006] ZACC 23, para 122-3, (South African Constitutional Court).

${ }^{115} I d$. at 122.
} 
homophobia would therefore not be capable of accommodation. There may of course be complex debates as to whether particular cultural or religious practices do breach the recognition dimension, particularly if their adherents believe they do not. However, the multidimensional structure gives a framework within which such debates can occur. The multidimensional approach can also assist in determining how to delimit the costs of reasonable accommodation. ${ }^{116}$

Familiar conflicts between redressing disadvantage and addressing stigma can also be approached through the multi-dimensional framework. Measures aimed at redressing socioeconomic disadvantage can themselves cause stigma and other recognition harms. Thus paying attention to both redressing disadvantage and the need to avoid stigma and stereotyping is essential to ensure that the design of social welfare rights is in tune with substantive equality. This can be seen by considering social welfare rights, which, although aimed at redressing disadvantage, can be highly intrusive and demeaning, as well as being based on gender stereotypes, such as assuming a male breadwinner or that women are the primary child-carers. The demonizing of welfare recipients as lazy and scroungers in modern rhetoric is a further demonstration. ${ }^{117}$ Lister points to the ways in which black people have been stereotyped and stigmatized through associating them with poverty and welfare dependency. ${ }^{118}$ Similarly, Porter describes a "disturbing pattern of scapegoating the poor" in Canada, where welfare recipients were seen in "unremittingly negative terms by the economically secure". ${ }^{119}$ Failing to address such stigma can undercut the goals of measures aimed at redressing disadvantage. For example, in the UK, free school meals have played a central role in the nutrition of children from poorer families; yet research shows that $20 \%$ of children who are entitled to free school meals do not use their entitlement. A third of pupils surveyed and over two-fifths of parents identified embarrassment or fear of being teased as

\footnotetext{
${ }^{116}$ Kelman, at 895.
}

117 This has been particularly true for single mothers in the US, who were specifically targeted by the welfare reform package when the Aid to Families with Dependent Children (AFDC) programme, which overwhelmingly supported single mothers, was replaced in 1996 with a welfare to work programme known as Temporary Assistance for Needy Families (TANF). James Midgley, Welfare Reform in the United States: Implications for British Social Policy, CASE/131 (2008).

118 RUTH LISTER, POVERTY 64 (2004).

${ }^{119}$ BRUCE PORTER , Claiming Adjudicative Space: Social Rights, Equality and Citizenship, in POVERTY: RIGHTS, Social CitizENSHIP AND Legal ACTIVISM 77-82 (Susan Boyd, Gwen Brodsky, Shelaigh Day \& Margot Young eds., 2007) 
factors which put them off taking their free meal. ${ }^{120}$ A similar point could be made about the design of affirmative action programmes, which need to take care to avoid stigmatising the beneficiaries.

The alliance with redressing disadvantage also helps us avoids the obstructive role played by dignity as seen in the Canadian and UK cases referred to above. Once both dimensions are taken into account, it makes no sense to say, as did the judges in Gosselin ${ }^{121}$ and Reynolds, that the disadvantage experienced by the applicants should not be seen as impacting on their dignity. Inflicting socio-economic disadvantage can itself constitute a recognition harm. ${ }^{122}$ This was highlighted in the South African case of Khosa, ${ }^{123}$ which concerned a legislative measure which confined the right to child benefit and old-age pensions to South African citizens, to the exclusion of permanent residents. In striking down this measure as a breach of equality, Mokgoro J emphasized that the consequences of exclusion were not only socioeconomic. In addition, the exclusion of permanent residents had a strong stigmatizing effect, creating the impression that they were inferior to citizens and less worthy of social assistance. Permanent residents were in effect 'relegated to the margins of society and deprived of what may be essential to enable them to enjoy other rights vested in them under the Constitution'. ${ }^{124}$

A final note concerns the role of agency or choice. While enhanced agency might seem to be an aim of substantive equality, liberal theories of choice have periodically been used to defeat equality claims on the grounds that the claimant could have chosen to avoid the consequences of a policy or practice. Individuals should thus only be protected against detrimental treatment on the basis of characteristics that are 'immutable' or cannot be changed by the applicants' own efforts. Substantive equality has brought with it an acknowledgement that that an individual should not be made to pay an unreasonable price for her choices. More fundamentally, the Sen's capabilities theory has illuminated the distinction between abstract

\footnotetext{
${ }^{120}$ Pamela Storey \& Rosemary Chamberlin, Improving the Take Up of Free School Meals, Thomas Coram Research Unit, Institute of Education. (2001), <http://www.cpag.org.uk/campaigns/school_meals.htm\#stigma)>.

${ }^{121}$ Gosselin, supra note 70 .

${ }^{122}$ See further Réaume, supra note 61 at 688

${ }^{123}$ Khosa, supra note 81.

${ }^{124} I d$. at para 77.
} 
choice and feasible options. Nevertheless, because agency needs to be carefully nuanced, it is not regarded as a separate dimension within the four dimensional framework. Instead, the appropriate notion of agency should be constructed within the four dimensions. For example, the need to redress disadvantage can override apparent choice when such choices are limited by that very disadvantage, or choices appear to entrench disadvantage. Similarly, recognition issues are based on the actual consequences flowing from one's identity, regardless of whether that identity is chosen. Under the transformative dimension, agency can be enhanced, through changing structures to widen the range of feasible options. However, choice is not the only value to strive: it should be complemented by valuing the situation people find themselves in regardless of choice.

\section{Conclusion}

I have argued in this paper that the right to equality continues to be a powerful source of energy for those who are disadvantaged, excluded, ignored or demeaned. The challenges it represents are not a reason to discard it. Instead, as witnessed by the strong and growing commitment at international and national levels, the impetus should be to develop it in substantive terms, which go beyond the right to equal treatment, equal opportunities or equal results, or a simplified egalitarianism or right to dignity. Instead, I have suggested that substantive equality should be developed in a multi-dimensional format, which recognises and addresses the distributional, recognition, structural and exclusive wrongs experienced by out-groups. These four dimensions of substantive equality create a complex and dynamic conception of the right to equality, which build on existing understandings but also invite further development and evolution. This approach does not of course solve all the challenges raised by the right to equality. Nevertheless, I hope that this contribution continues the vibrant process of enriching the right to equality through conversation and engagement. 
